\title{
APLIKASI PENENTUAN HARGA JUAL KAMAR PADA PERUSAHAAN JASA PERHOTELAN MENGGUNAKAN METODE ACTIVITY BASED COSTING (ABC)
}

\author{
Ami Fauzijah, M. Yasir Zain \\ Jurusan Teknik Informatika, Fakultas Teknologi Industri, Universitas Islam Indonesia \\ Jl. Kaliurang Km. 14 Yogyakarta 55501 \\ Telp. (0274) 895287 ext. 122, Faks. (0274) 895007 ext. 148 \\ E-mail:ami@fti.uii.ac.id
}

\begin{abstract}
ABSTRAK
Metode activity based costing yang hadir di tengah-tengah dunia accounting cukup membantu mengurangi overcosting atau undercosting yang diakibatkan oleh terjadinya distorsi dalam pembebanan biaya. Pembangunan aplikasi penentuan harga jual kamar menggunakan metode activity based costing diharapkan menjadi alat bantu pengelola hotel untuk menentukan harga jual kamar. Pendataan biaya yang dikelompokkan dalam beberapa kategori dan cost driver dilakukan tiap periode (per bulan) selama satu tahun. Dari data-data yang telah tersimpan akan didapat harga pokok kamar dan setelah ditambah dengan beberapa komponen lain seperti mark-up dan VAT (Value Added Tax) atau PPN, maka akan didapat harga jual kamar.
\end{abstract}

Kata kunci: metode $A B C$, cost driver, cost pool, depresiasi, nilai residu.

\section{PENDAHULUAN}

Semakin menjamurnya perusahaan jasa terutama yang bergerak di bidang pariwisata dan perhotelan, menyebabkan semakin ketatnya persaingan antar hotel. Keberhasilan dalam memenangkan persaingan tersebut ditentukan oleh beberapa hal antara lain quality, cost dan services.

Services adalah kuantitas atau ragam pelayanan yang disediakan pihak hotel terhadap pelanggannya misalnya fasilitas kolam renang, restoran, fitness center, bar, dan lain sebagainya. Quality merupakan kualitas pelayanan terhadap konsumen, hal ini lebih menekankan pada kepuasan konsumen terhadap satu jenis pelayanan. Kebersihan kolam yang selalu terjamin, rasa masakan yang sesuai dengan selera konsumen, alat-alat fitness yang lengkap dan berfungsi dengan baik, keramahan karyawan hotel merupakan contoh dari kualitas pelayanan yang disediakan pihak hotel terhadap tamu atau konsumennya.

Selain quality dan services, cost merupakan faktor yang sangat berpengaruh dalam perebutan hati para konsumen maupun calon konsumen. Cost adalah jumlah nominal yang harus dibayarkan oleh konsumen atas pelayanan yang diberikan oleh pihak hotel atau penyedia jasa. Jika ada perbandingan antara beberapa hotel dengan quality dan services yang sama dalam hal penentuan harga dan mengabaikan faktor loyalitas konsumen terhadap produsen atau penyedia 
jasa, konsumen akan cenderung memilih hotel yang lebih murah. Untuk itu diperlukan perhitungan yang maksimal (Kotler, 2000).

Perhitungan harga jual produk atau jasa dengan menggunakan sistem biaya tradisional dirasa kurang maksimal. Sistem biaya tradisional didasarkan pada biaya material langsung dan biaya tenaga kerja langsung. Sedangkan biaya overheadnya dialokasikan ke semua unit produk/jasa yang dihasilkan sehingga sering terjadi distorsi.

Atas dasar kelemahan sistem akuntansi biaya tradisional tersebut maka timbul pendekatan baru dalam pembebanan biaya yang disebut dengan Activity Based Costing (ABC) System atau sistem akuntansi biaya atas dasar aktivitas. Sistem $\mathrm{ABC}$ menghasilkan informasi yang dapat membatasi distorsi yang disebabkan oleh pengalokasian sistem akuntansi biaya tradisional.

Penelitian ini bertujuan untuk membangun aplikasi yang dapat digunakan untuk menentukan harga jual kamar pada perusahaan jasa perhotelan berdasarkan metode Activity Based Costing (ABC).

\section{DASAR TEORI}

\subsection{Definisi Activity Based Costing (ABC)}

Meskipun pembicaraan mengenai $A B C$ System sejauh ini lebih menitikberatkan pada perusahaan manufaktur, $A B C$ System juga dapat diterapkan pada perusahaan yang bergerak di bidang pelayanan atau jasa. Setiap perusahaan jasa mempunyai kegiatan dan hasil yang menempatkan permintaan dalam kegiatannya. Bagaimanapun juga terdapat perbedaan-perbedaan mendasar antara perusahaan jasa dan perusahaan yang menghasilkan barang (manufaktur). Kegiatan dalam perusahaan manufaktur cenderung sama dan dijalankan dengan cara yang sama pula. Hal tersebut tidak dapat disamakan dalam perusahaan jasa. Perbedaan pokok lainnya adalah mengenai definisi hasil atau produk. Untuk perusahaan manufaktur, produk secara mudah didefinisikan sebagai barang atau benda berujud, tetapi untuk perusahaan jasa, definisi hasil lebih sulit. Hasil dari perusahaan jasa tidak dapat diraba.

Dalam buku Intermediate Accounting (Baridwan, 2000) dituliskan definisidefinisi ABC oleh Gayle (1993) mendefinisikan ABC sebagai berikut:

$A B C$ mengakui bahwa pelaksanaan aktivitas menimbulkan konsumsi sumber daya yang dicatat sebagai biaya. "Kalkulasi biaya berbasis transaksi" adalah nama lain untuk $A B C$. Tujuan $A B C$ adalah mengalokasikan biaya ke transaksi dari aktivitas yang dilakukan dalam suatu organisasi, dan kemudian mengalokasikan biaya tersebut secara tepat ke produk sesuai dengan pemakaian aktivitas tiap produk.

Sedangkan Wayne et.al (1991) mendefinisikan ABC sebagai berikut:

Pengalokasian dan pengalokasian kembali biaya ke obyek biaya dengan dasar aktivitas yang menyebabkan biaya $A B C$ berdasarkan premis/dasar pemikiran bahwa aktivitas menyebabkan biaya dan biaya aktivitas harus dialokasikan ke obyek biaya dengan dasar aktivitas biaya tersebut dikonsumsikan. $A B C$ menelusuri biaya ke produk dengan dasar aktivitas yang digunakan untuk menghasilkan produk tersebut. 
Suatu metode kalkulasi biaya yang menciptakan suatu kelompok biaya untuk setiap kejadian atau transaksi (aktivitas) dalam suatu organisasi yang berlaku sebagai pemacu biaya. Biaya overhead kemudian dialokasikan ke produk dan jasa dengan dasar jumlah dari kejadian atau transaksi tersebut yang produk atau jasa hasilkan (Garrison, 1991).

Horngren et al. (1993) mendefinisikan ABC sebagai berikut:

Suatu pendekatan kalkulasi biaya yang memfokuskan pada aktivitas sebagai obyek biaya yang fundamental. ABC menggunakan biaya dari aktivitas tersebut sebagai dasar untuk mengalokasikan biaya ke obyek biaya yang lain seperti produk, jasa atau pelanggan.

Hansen dan Maryanne (1992) mendefinisikan ABC sebagai berikut:

Suatu sistem kalkulasi biaya yang pertama kali menelususri biaya ke aktivitas dan kemudian ke produk.

Anderson dan Harold (1992) mendefinisikan ABC sebagai berikut:

Suatu sistem akuntansi yang memfokus pada aktivitas yang dilakukan untuk memproduksi produk. Aktivitas menjadi titik akumulasi biaya yang fundamental. Biaya ditelusuri ke aktivitas, dan aktivitas ditelusuri ke produk berdasarkan pemakaian aktivitas dari setiap produk.

Hubungan untuk mengalokasikan biaya ke produk dinyatakan dalam Gambar 1.

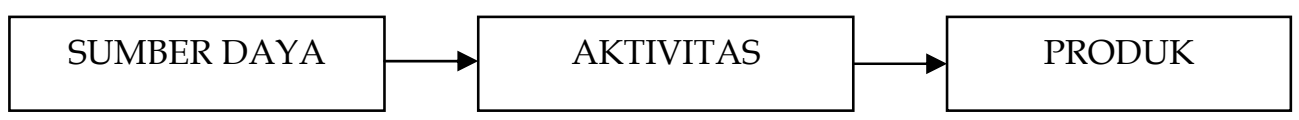

Gambar 1. Hubungan alokasi biaya ke produk

Heitger et.al (1992) dan kawan-kawan mendefinisikan Activity Costing atau Activity-based costing sebagai berikut:

Proses mengidentifikasi sumber atau penyebab biaya dalam manufakturing atau aktivitas usaha lain. Sumber biaya ini, dinamakan pemacu/pemandu/penyebab biaya, digunakan sebagai dasar untuk mengidentifikasi dan mengalokasikan biaya ke aktivitas dan akhirnya ke produk yang mengkonsumsi aktivitas ini.

\subsection{Konsep Dasar Activity Based Costing}

Konsep dasar dari Activity Based Costing dapat dilihat pada Gambar 2. Dari Gambar 2 dapat dijelaskan bahwa bagian vertikal menggambarkan kebutuhan organisasi untuk membebankan sumber daya ke aktivitas dan selanjutnya dibebankan ke obyek biaya (pelanggan atau produk). Sedangkan bagian 
horisontal menggambarkan kebutuhan organisasi lain yaitu informasi yang menjelaskan apa penyebab terjadinya pekerjaan atau bagaimana pekerjaan tersebut dilakukan.

Dalam merancang Activity Based Costing System, kegiatan untuk memproduksi dan menjual produk dalam perusahaan yang menghasilkan berbagai jenis output dapat diklasifikasikan ke dalam 4 kelompok besar, (1) facility-sustaining activities, (2) product-sustaining activities, (3) batch-related activities, dan (4) unit level activities. (Wilkinson, 2000)

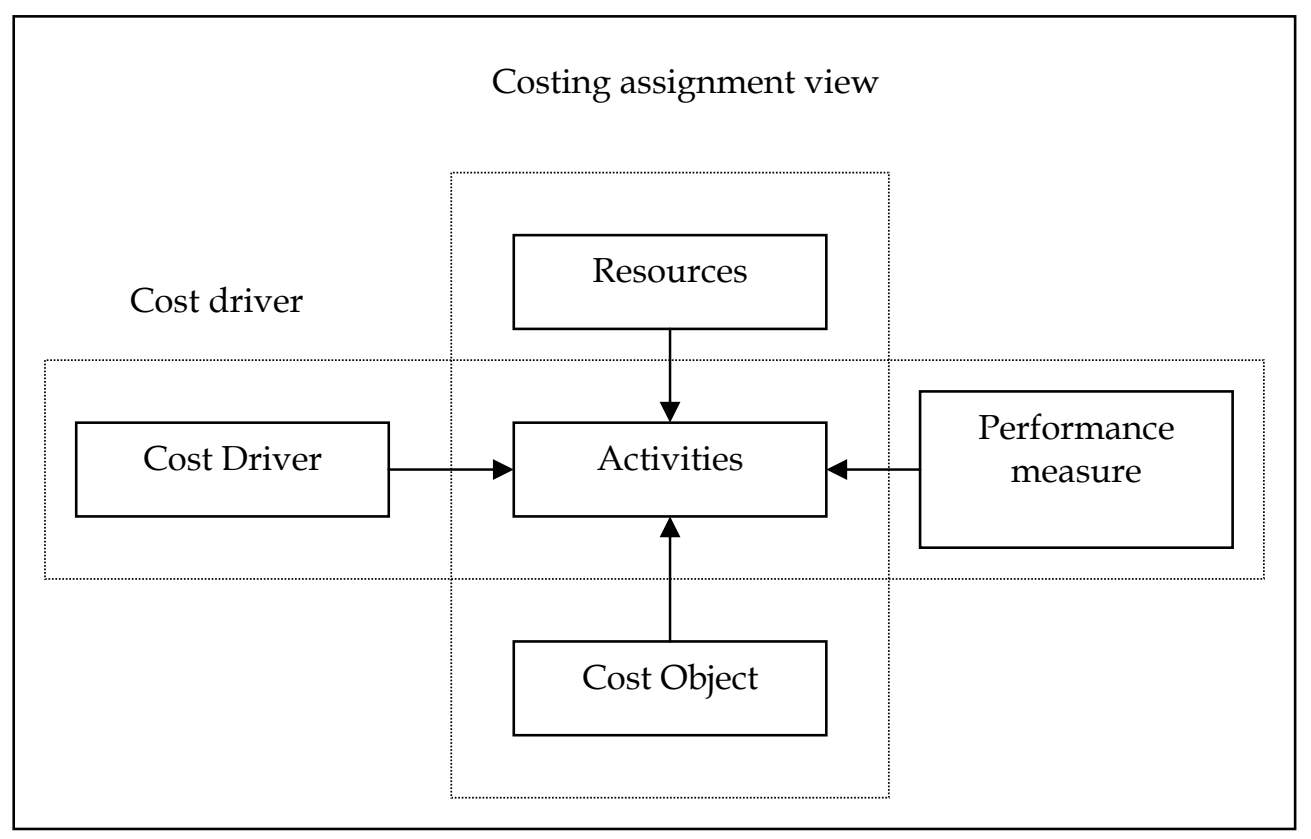

Gambar 2. Konsep Dasar ABC System

\section{METODOLOGI PENELITIAN}

Langkah-langkah dalam penelitian ini sebagai berikut:

1. Menyediakan data-data utama yang diperlukan yaitu:

Biaya gaji dan Upah Karyawan

Biaya administrasi dan umum

Biaya listrik

Biaya alat kebersihan

Biaya depresiasi bangunan

Biaya depresiasi inventaris

2. Menyediakan data-data pendukung meliputi:

a. Type (jenis) kamar, Jumlah kamar dan jumlah kamar terjual.

b. Data Luas kamar tiap type

c. Data pemakian daya listrik (watt) dan jumlah biaya yang harus ditanggung.

3. Penggolongan aktivitas berdasarkan kategori aktivitas. 
4. Penentuan cost driver.

Cost driver (pemacu biaya) didefinisikan sebagai faktor yang digunakan untuk mengukur bagaimana biaya terjadi atau cara untuk membebankan biaya pada aktivitas atau produk. Cost driver digunakan untuk mengetahui konsumsi biaya oleh aktivitas dan konsumsi aktivitas oleh produk. Secara praktis, cost driver menunjukkan dimana biaya harus dibebankan dan seberapa besar biayanya.

Cost driver merupakan penyebab terjadinya biaya, sedangkan aktivitas adalah dampaknya. Dalam sistem ABC digunakan beberapa pemacu biaya, sedangkan pada sistem biaya konvensional hanya digunakan satu pemacu biaya tertentu sebagai basis, misalnya jam mesin (Halim, 1997).

\section{Penentuan Cost Pool}

Agar dapat dimasukkan ke dalam suatu kelompok biaya (cost pool) aktivitas overhead harus dihubungkan secara logis dan mempunyai rasio konsumsi yang sama yang menunjukkan eksistensi dari sebuah cost driver. Cost pool dapat ditentukan dengan menggunakan rumus persamaan 1 (Tunggal, 1992).

$$
\text { Cost pool }=\frac{\text { Jumlah Biaya }}{\text { Cost Driver }}
$$

6. Pembebanan biaya dalam cost pool dengan cost driver.

7. Menganalisis prosedur kerja menurut bagian-bagian sistem sebagai berikut:

a. Front Office

Pencatatan data pendukung dilakukan ketika proses input data-data hotel terutama input data fasilitas kamar.

Pencatatan transaksi dilakukan oleh Front office ketika tamu datang melakukan reservation atau registration. Jika transaksi yang dilakukan adalah registration, berarti tamu hotel sudah melakukan check-in dan mulai dari sinilah pencatatan terjualnya kamar dilakukan.

Front office kembali mencatat transaksi ketika tamu melakukan proses check-out. Dari tahap ini dapat diketahui berapa lama tamu menginap dan hasil penghitungan ini berpengaruh pada hitungan occupancy (tingkat hunian kamar) atau dalam sistem ini merupakan jumlah kamar terjual.

b. Personalia

Personalia mendata semua data karyawan mulai dari top level management sampai level terendah yaitu bottom level management.

Personalia juga mencatat semua transaksi yang berhubungan dengan gaji dan upah karyawan tersebut setiap bulannya.

c. Manajemen

Pihak manajemen melakukan input data-data yang harus diisikan misalnya, biaya administrasi dan umum, biaya listrik dan lain sebaginya.

Dengan data yang sudah tersedia seperti biaya gaji dan upah karyawan maupun occupancy dapat diketahui harga jual kamar kamar. 


\section{HASIL DAN PEMBAHASAN}

\subsection{Implementasi}

Aplikasi penentuan harga jual kamar dengan metode $A B C$ terdiri atas beberapa proses seperti ditunjukkan dalam Gambar 3.

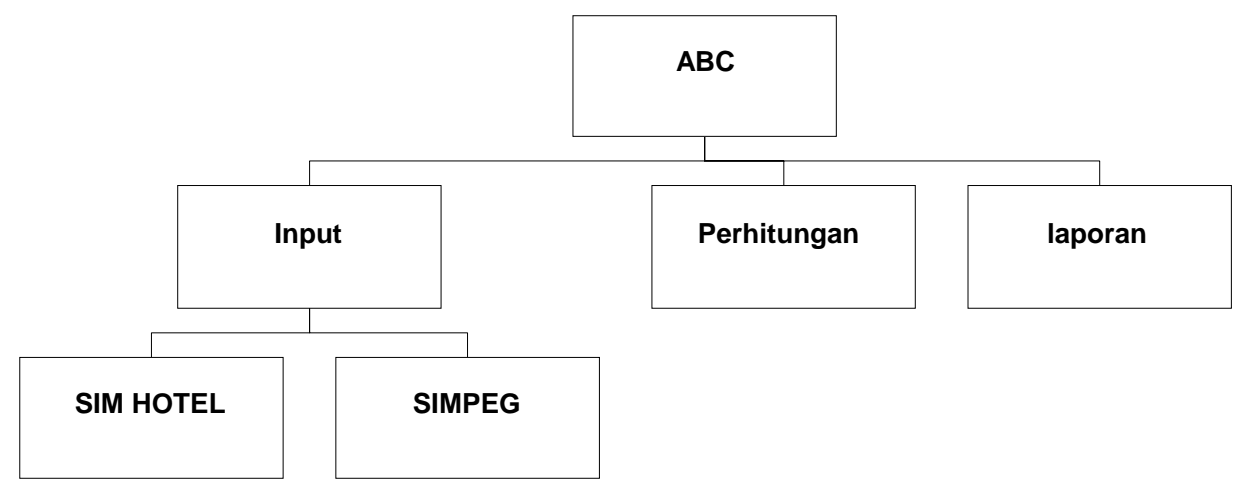

Gambar 3. Bagan berjenjang aplikasi ABC

Lingkungan pengembangan dari Aplikasi penentuan harga jual kamar adalah proses input data, pencarian data dan menampilkan data itu sendiri. Data aktivitas biaya lebih banyak diisikan secara kumulatif setiap periode, sehingga aplikasi ini tidak mencatat transaksi ekonomi secara detail

Perangkat Lunak yang digunakan dalam membangun sistem adalah Borland Delphi 6 dan MySQL. Perangkat lunak Borland Delphi dipilih karena berbasis GUI (Graphical user Interface) yang memudahkan dalam mengembangkan sebuah software.

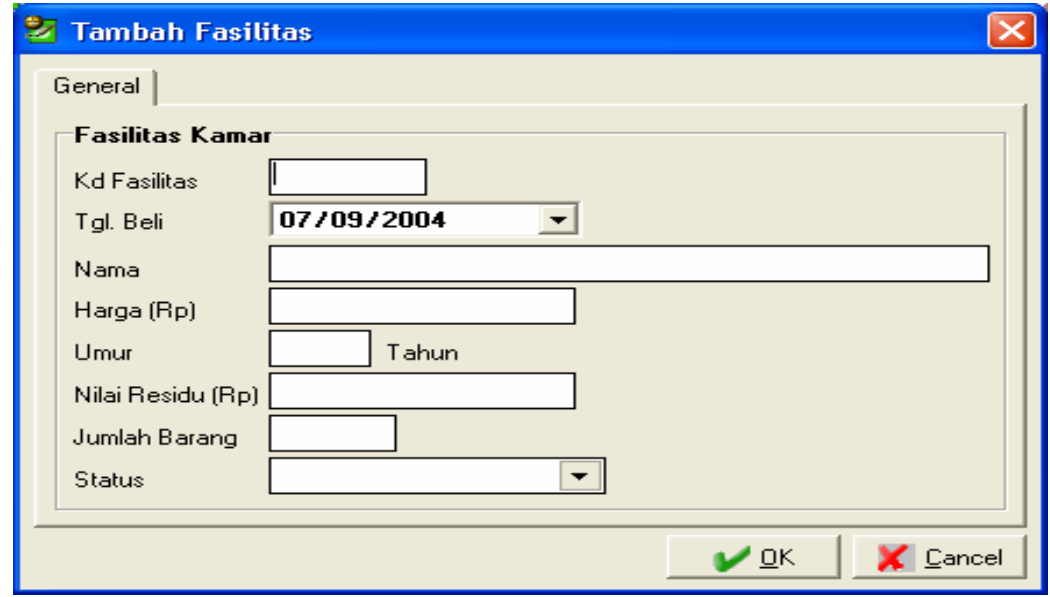

Gambar 4. Tampilan form input fasilitas kamar 
Implememtasi dari aplikasi penentuan harga jual ini dibagi menjadi tiga bagian yaitu input, display dan laporan. Input dalam aplikasi ABC ini terdiri atas beberapa form antara lain form login, input fasilitas kamar, input bangunan (Gambar 6), input komponen aktivitas biaya (Gambar 7), input biaya aktivitas (Gambar 8), dan form harga jual kamar (Gambar 9).

Setelah mengisikan form input fasililtas kamar, selanjutnya akan dilakukan penghitungan depresiasi dengan metode garis lurus menggunakan rumus persamaan 2. (Tunggal, 1992)

$$
\text { Depresiasi }=\frac{H P-N S}{n}
$$

Keterangan:

HP = Harga Perolehan

NS = Nilai Sisa (Residu)

$\mathrm{n}=$ Taksiran umur kegunaan

Perhitungan depresiasi dengan garis lurus ini didasarkan pada asumsiasumsi sebagai berikut:

a. Kegunaan ekonomis dari suatu aktiva akan menurun secara proporsional setiap periode.

b. Biaya reparasi dan pemeliharaan tiap-tiap periode jumlahnya relatif tetap.

c. Kegunaan ekonomis berkurang karena lewat waktu.

d. Penggunaan (kapasitas) aktiva tiap-tiap periode relatif tetap.

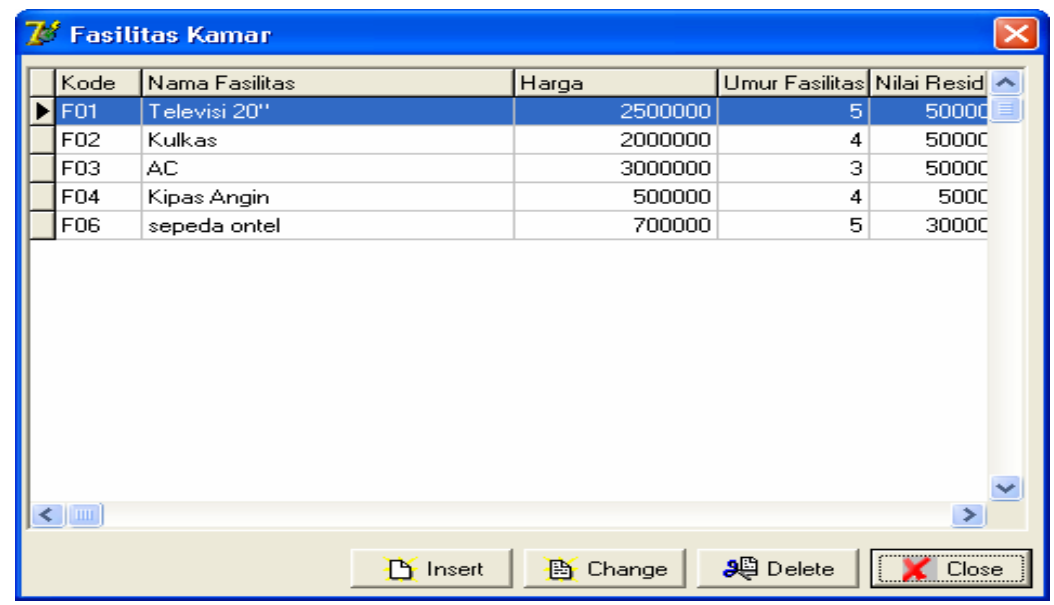

Gambar 5. Tampilan form display fasitas kamar

Display fasilitas kamar digunakan untuk menampilkan data-data fasilitas kamar yang sudah diinputkan. Tampilan display Fasilitas kamar terlihat seperti pada Gambar 5. 


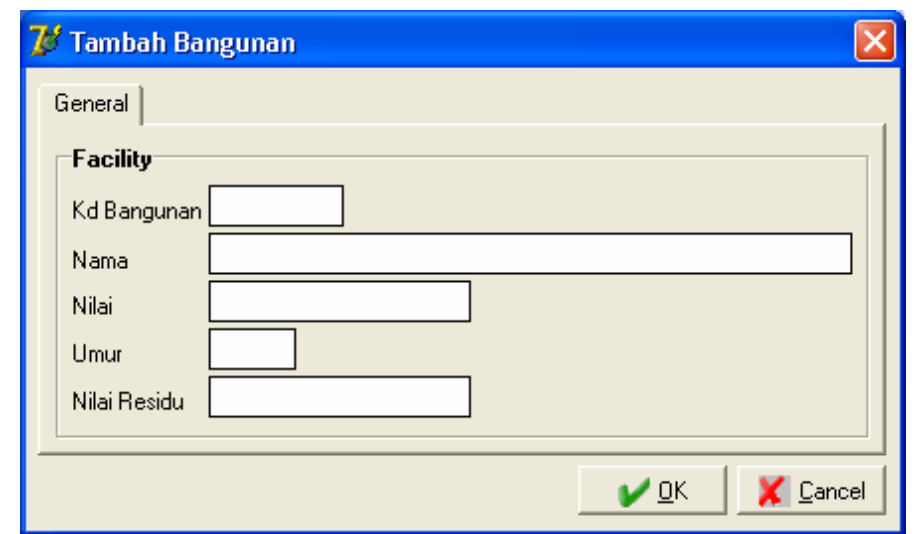

Gambar 6. Tampilan form input bangunan

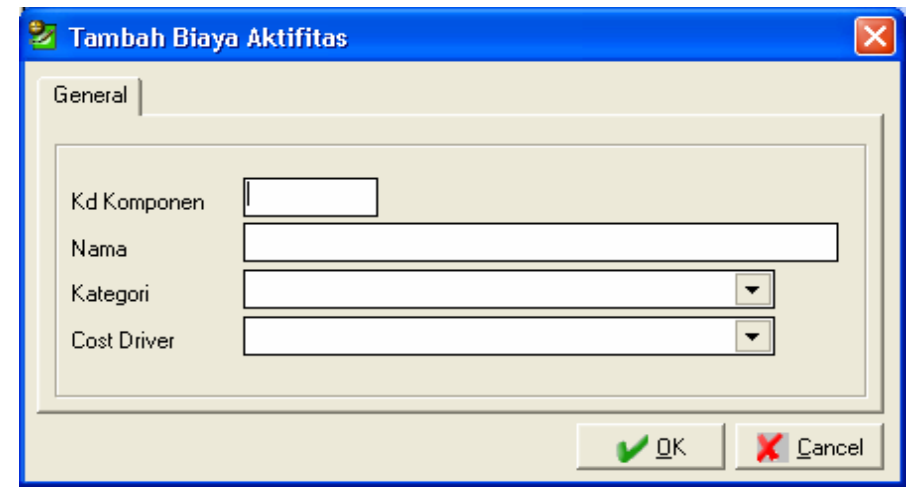

Gambar 7. Tampilan form input komponen aktivitas biaya

Sebelum penentuan harga jual kamar diproses, hal pertama yang dilakukan adalah mencari nilai harga pokok. Penentuan nilai harga pokok dihitung berdasarkan data dari aplikasi SIM HOTEL dan SIMPEG karena data yang dibutuhkan meliputi data kamar terjual, kilo watt pemakaian, luas lantai, jumlah linen, dan total gaji. Semua data diakumulasi dalam periode satu tahun. Dalam form pada Gambar 9 hanya diperlukan input data markup dan PPN. Selanjutnya, jika diklik tombol proses maka akan dihitung harga jual kamar berdasarkan metode ABC. 


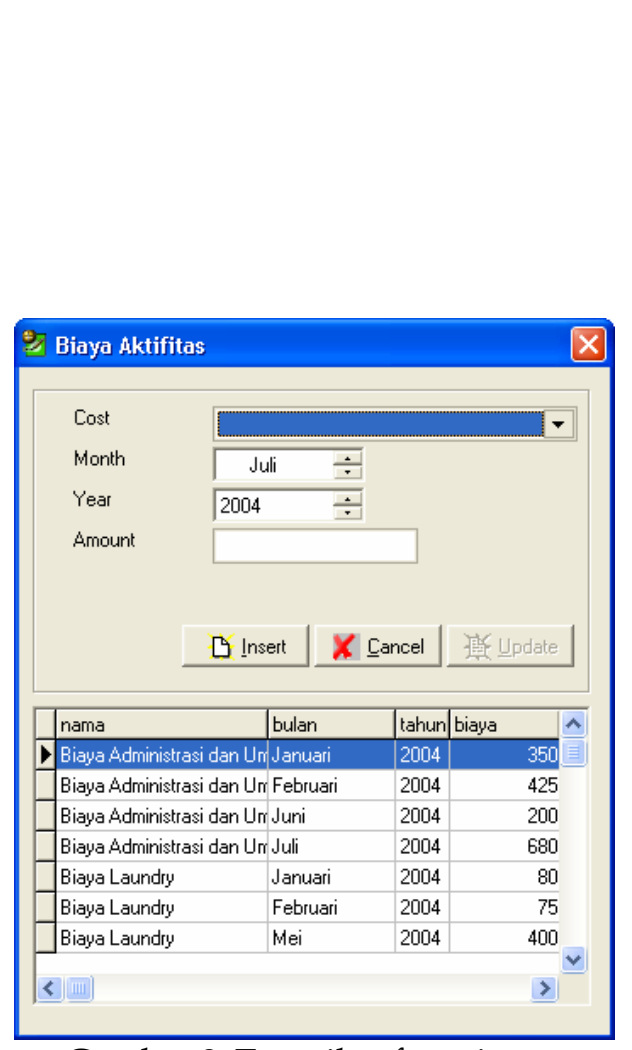

Gambar 8. Tampilan form input komponen aktivitas biaya

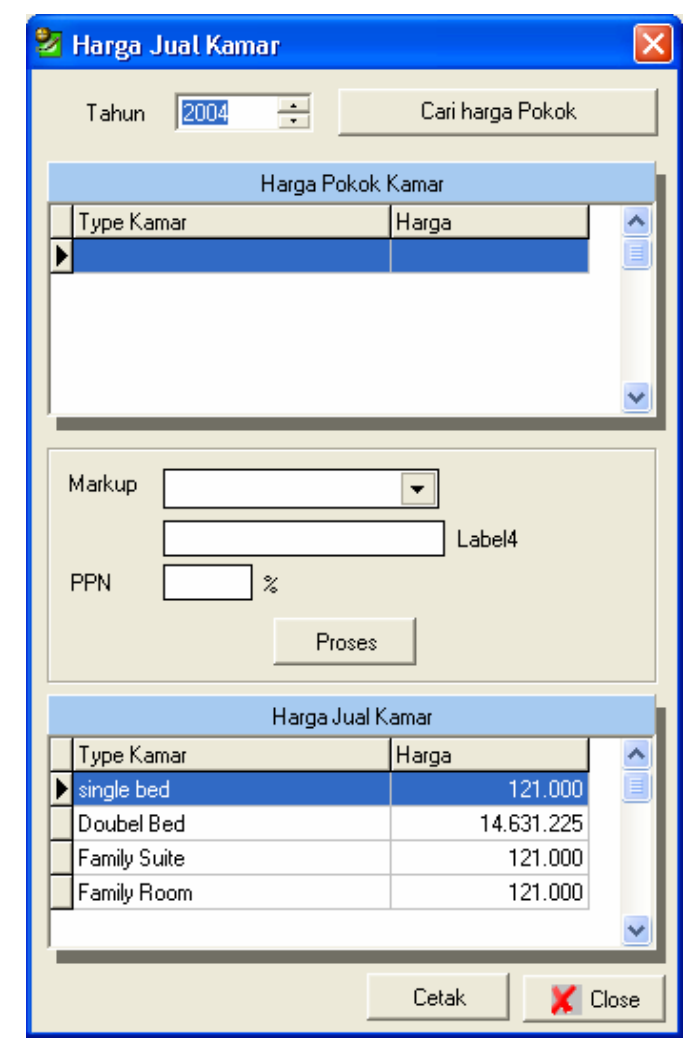

Gambar 9. Tampilan form proses penentuan harga jual

\subsection{Keunggulan dan kekurangan aplikasi}

Keunggulan aplikasi ini adalah sebagai berikut:

a. penghitungan harga jual kamar menjadi lebih mudah,

b. proses penyediaan informasi menjadi lebih cepat, dan

c. Aplikasi penghitungan harga jual kamar dengan metode $A B C$ terpisah dengan SIM HOTEL dan SIMPEG sehingga aplikasi metode ABC ini dapat digunakan untuk Hotel lain yang sudah mempunyai SIM HOTEL dan SIMPEG.

Kekurangan aplikasi ini adalah:

a. Variabel penghitungan harga jual masih belum detail,

b. Aplikasi penghitungan harga jual kamar dengan metode $A B C$ terpisah dengan SIM HOTEL dan SIMPEG sehingga jika aplikasi metode ABC dipakai untuk Hotel yang lain harus ada sinkronisasi lagi dengan database yang tersedia.

\section{SIMPULAN DAN SARAN}

Metode Activity Based Costing dapat digunakan untuk menentukan harga jual kamar pada perusahaan jasa perhotelan dalam bentuk aplikasi komputer sehingga mampu menghasilkan informasi harga pokok dan harga jual kamar yang 
dapat dijadikan pertimbangan dalam menentukan jumlah keuntungan yang diharapkan. Pengembangan aplikasi berikutnya diharapkan sistem dapat menangani perubahan data cost driver dan cost pool.

\section{PUSTAKA}

Baridwan, Z. (2000). Intermediate Accounting, Edisi 7, Yogyakarta: BPFE.

Halim, A. (1997). Dasar-dasar Akuntansi Biaya. Yogyakarta: BPFE.

Kotler, P. (2000). Manajemen Pemasaran, Jakarta: Prenhallindo.

Tunggal, A. W. (1992). Activity Based Costing Suatu Pengantar, Jakarta: PT. Rineka Cipta.

Wilkinson, J. W. (2000). Accounting Information System, New York: John Willey and sons., Inc. 